\title{
BIOGEOCHEMICAL CYCLING AND ENVIRONMENTAL STABILITY OF PLUTONIUM RELEVANT TO LONG-TERM STEWARDSHIP OF DOE SITES
}

\author{
A.J. Francis (PI), J.B. Gillow and C.J. Dodge \\ Environmental Sciences Department, Brookhaven National Laboratory, Upton NY
}

\section{RESEARCH OBJECTIVE}

$\mathrm{Pu}$ is generally considered to be relatively immobile in the terrestrial environment, with the exception of transport via airborne and erosion mechanisms. More recently the transport of colloidal forms of $\mathrm{Pu}$ is being studied as a mobilization pathway from subsurface contaminated soils and sediments. The overall objective of this research is to understand the biogeochemical cycling of $\mathrm{Pu}$ in environments of interest to long-term DOE stewardship issues. Microbial processes are central to the immobilization of Pu species, through the metabolism of organically complexed $\mathrm{Pu}$ species and $\mathrm{Pu}$ associated with extracellular carrier phases and the creation of environments favorable for retardation of Pu transport.

\section{RESEARCH PROGRESS AND IMPLICATIONS}

This report summarizes work after 2 years of a 3 year project. This is a collaborative project between BNL, Colorado School of Mines and Texas A\&M University, Galveston.

\section{CHARACTERIZATION OF PLUTONIUM-CONTAMINATED RFETS SOIL}

Soil samples from the Rocky Flats Environmental Technology Site (RFETS) 903 pad 'lip' area, the source-term zone for Pu contamination at the site. Synchrotron micro-X-ray fluorescence ( $\mu$-SXRF) analysis of the soil indicates that their elemental composition are very similar (Figure 1A, B). The analysis shows the presence of $\mathrm{Zr}, \mathrm{Y}, \mathrm{Sr}, \mathrm{Rb}, \mathrm{Pb}, \mathrm{Re}, \mathrm{Fe}$, and As in the soil. The soil was scanned with incident beam energy above the Pu $\mathrm{L}_{\text {III }}$ absorption edge; however the Pu L $\alpha$ x-ray emission at $14.28 \mathrm{keV}$ was not detected since the concentration of ${ }^{239,240} \mathrm{Pu}$ in the soil $(1.6 \mathrm{ng} / \mathrm{g}$ in the 2004 soil and $3.9 \mathrm{ng} / \mathrm{g}$ in the $1997 \mathrm{soil})$ was below the detection limit for this method. In addition, the Sr L $\alpha$ emission had a similar energy (14.16 keV) resulting in overlapping signals which interfere with its detection.

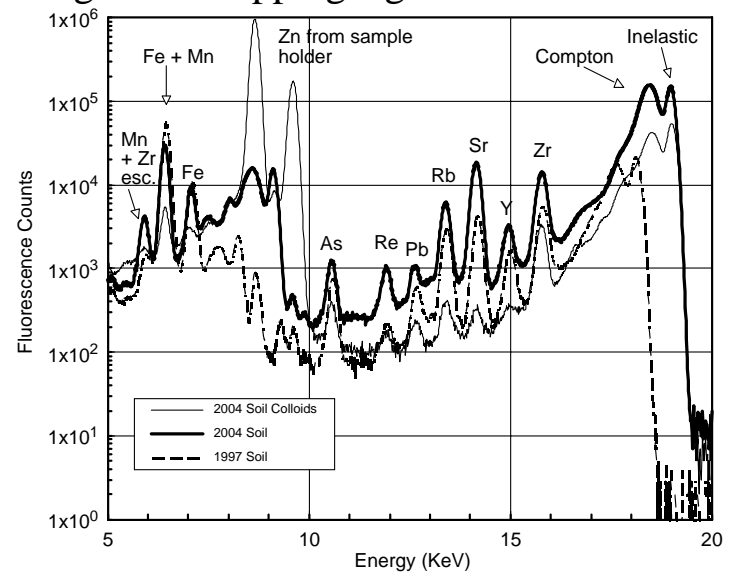

A

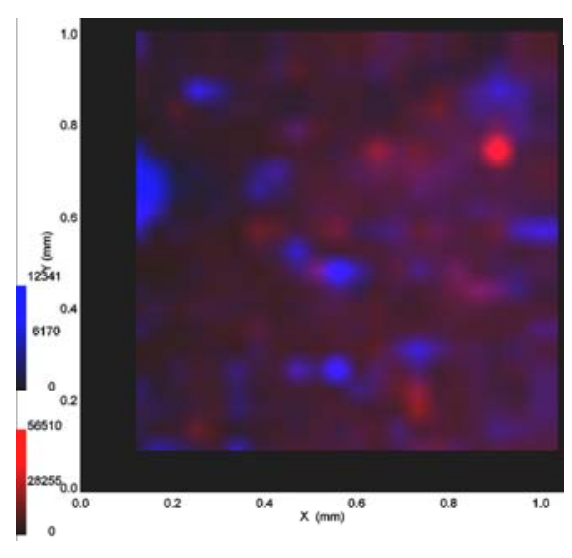

B

Figure 1. Comparison of synchrotron $\mu$-XRF analysis (A) of RFETS soils in 1997 and 2004; and elemental mapping of 2004 soil for iron (red) and strontium (blue) shows Fe is present as discrete particles which are not correlated with Sr. 


\section{CHARACTERIZATION OF PLUTONIUM SPIKED RFETS SOIL}

Rocky Flats soil sample was spiked with ${ }^{242} \mathrm{Pu}$ to increase the detection limit for analysis. Figure 2A shows the epifluorescence micrograph of soil recovered from Rocky Flats (DAPI stain, 1000x magnification). The DAPI-stained blue regions contain DNA indicating the presence of microorganisms. Elemental mapping using $\mu$-SXRF on region a $300 \mu \mathrm{m}$ x $300 \mu \mathrm{m}$ of the soil shows the presence of Fe (Figure 2B) and ${ }^{242} \mathrm{Pu}$ (Figure 2C). The coincidence of the regions at the top of the map indicates a strong correlation between Fe and the added $\mathrm{Pu}$.
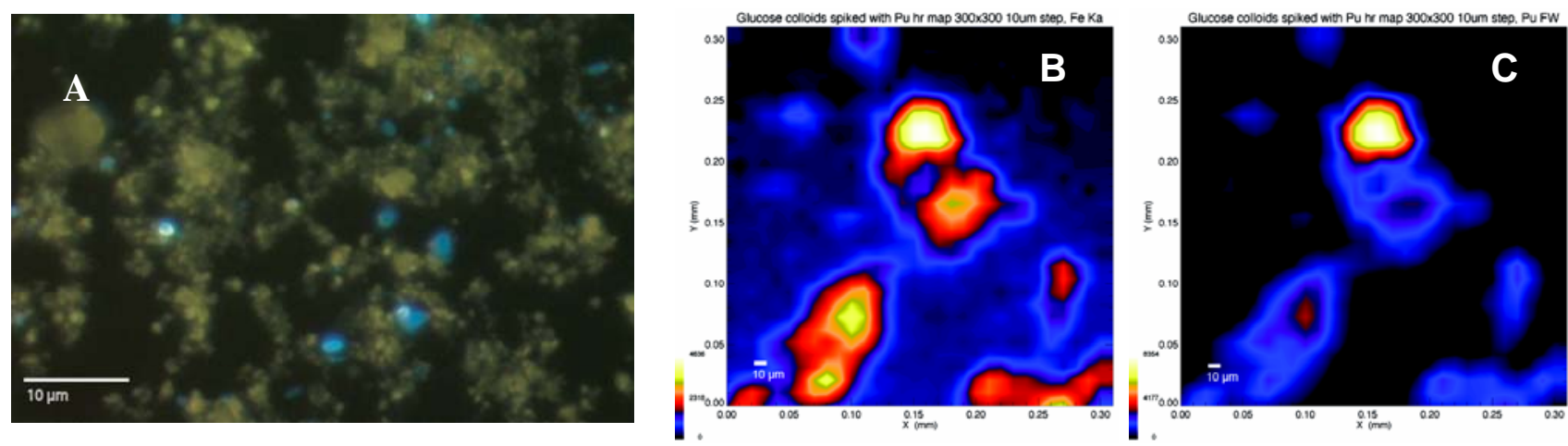

Figure 2. Epifluorescence micrograph of RFETS from soil incubation experiments showing the presence of indigenous bacteria (A); $\mu$-SXRF map of soil showing $\mathrm{Fe}(\mathrm{B})$ and $\mathrm{Pu}(\mathrm{C})$ isolated from soil.

\section{BIOTRANSFORMATION OF PLUTONIUM IN RFETS SOIL}

Rocky Flats soil collected in 2004 was characterized for its total Pu content by Texas A\&M University at Galveston and contained $100 \mathrm{pCi}^{239,240} \mathrm{Pu} \mathrm{g}^{-1}$ soil). The soil $(<2 \mathrm{~mm})$ was added to anaerobic serum bottles, prereduced nutrient solution was added, and the following treatments were included: i) deionized water (unspiked); ii) DI water $+{ }^{242} \mathrm{Pu}$ spike; iii) glucose $(0.5 \%)+\mathrm{NH}_{4} \mathrm{Cl}(0.015 \%)$ (unspiked); iv) glucose $(0.5 \% \mathrm{w} / \mathrm{v})+\mathrm{NH}_{4} \mathrm{Cl}(0.015 \% \mathrm{w} / \mathrm{v})+{ }^{242} \mathrm{Pu}$ spike; v) lactate $(0.5 \% \mathrm{w} / \mathrm{v})+\mathrm{NH}_{4} \mathrm{Cl}(0.015 \%)$ (unspiked); and, vi) lactate $(0.5 \% \mathrm{w} / \mathrm{v})+\mathrm{NH}_{4} \mathrm{Cl}$ $(0.015 \%)+{ }^{242} \mathrm{Pu}$ spike. The spiked samples from 1997 soil received $530 \mathrm{pCi}{ }^{242} \mathrm{Pu}$ per ml and the 2004 soil samples received $1600 \mathrm{pCi}^{242} \mathrm{Pu}$ per ml added as $\mathrm{Pu}(\mathrm{IV})$-nitrate. This was done to obtain an adequate signal using liquid scintillation counting (LSC) so that the solid/solution partitioning of $\mathrm{Pu}$ could be determined. The ${ }^{242} \mathrm{Pu}$ spike also simulated fresh deposition of $\mathrm{Pu}$ hydroxide to the soil. The bottles were incubated in the dark without shaking at room temperature $\left(22 \pm 2^{\circ} \mathrm{C}\right)$.

Bacterial growth. The rate and extent of bacterial growth was determined on a $0.45 \mu \mathrm{m}$ filtered aliquot for i) $\mathrm{pH}$ and Eh; ii) iron (Fe (II) and total Fe); iii) ${ }^{242} \mathrm{Pu}$, and iv) glucose, lactate, and organic acid metabolites. The ambient ${ }^{239,240} \mathrm{Pu}$ in the 1997 soil was determined after 45 days incubation; for the spiked 2004 soil it was determined after 77 days incubation. At this time ${ }^{242} \mathrm{Pu}$ and iron was also determined in the citrate-bicarbonate dithionite (CBD) extract of the microbial samples.

The $\mathrm{pH}$ change over the course of the experiment from fermentation of carbon source using the soil obtained in 2004 is shown in Figure 3A. Glucose was fermented by indigenous soil microbes with total gas (25 mmoles) and acetic and butyric acid production (45 $\mathrm{mM}$ total) (data not shown). The $\mathrm{pH}$ decreased to 5.0 from 7.6 after 10 -h in the presence of glucose. Lactate was fermented to acetate and propionate ( $40 \mathrm{mM}$ total), and the production of gas (20 mmoles total) 
with relatively little decrease in $\mathrm{pH}$ to 7.0 from 7.6. Unamended samples did not produce gas or organic acid metabolites and the $\mathrm{pH}$ remained fairly constant at 7.6. Concomitant with microbial activity in glucose and lactate amended samples was dissolution of the iron in the soil (Figure 3B). The glucose amended samples showed the highest amount of $\mathrm{Fe}^{2+}$ in solution (50\% w/w of the total iron in the soil) with $4.5 \mathrm{mM}$ and $3.8 \mathrm{mM}$ ferrous ion solubilized as result of change in $\mathrm{pH}$ and bacterial reduction of $\mathrm{Fe}(\mathrm{III})$ to $\mathrm{Fe}(\mathrm{II})$ in the 2004 and 1997 soil samples, respectively. A minor amount of $\mathrm{Fe}^{2+}(0.20 \mathrm{mM})$ was detected in the lactate amended samples and no ferrous ion was present in the unamended soils.
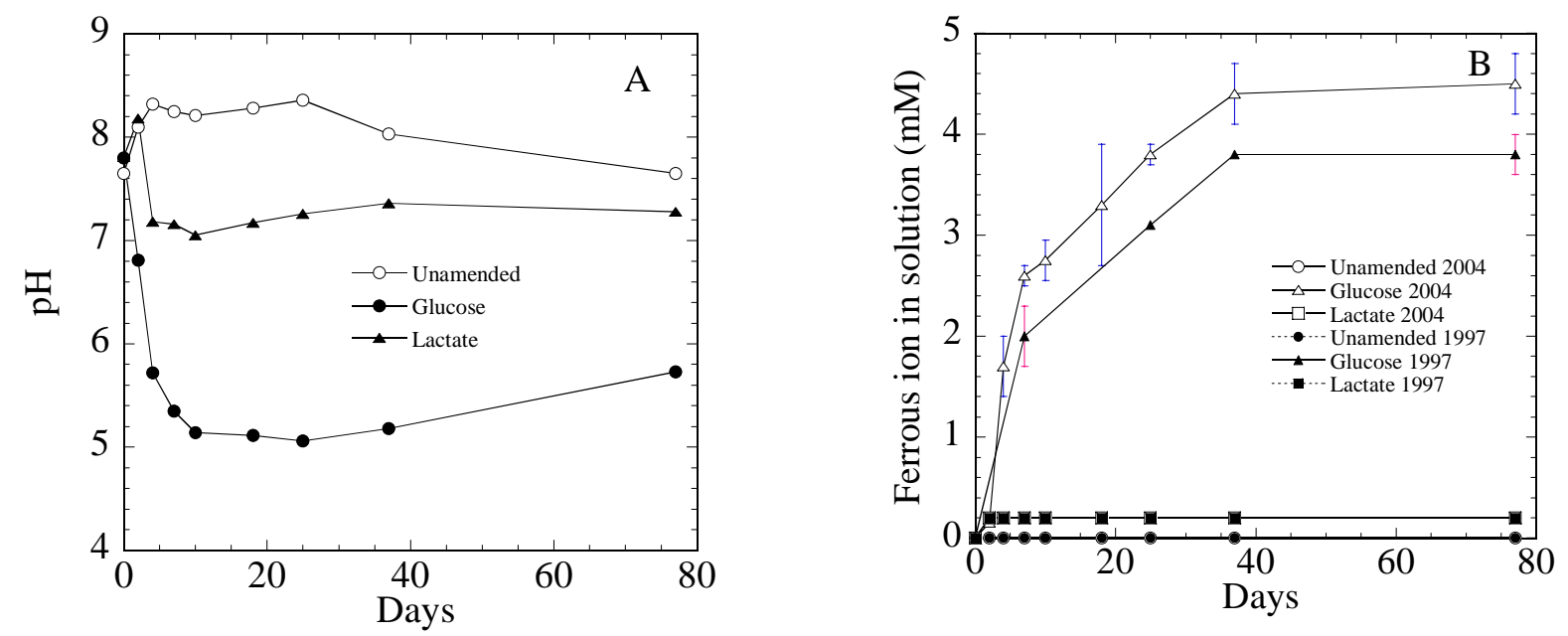

Figure 3. The $\mathrm{pH}$ of incubation experiment with Rocky Flats soil (2004) (unspiked samples not shown) (A); Fe dissolution from Rocky Flats soil during incubation experiments with soil collected in 1997 and 2004 (B).

\section{DETERMINATION OF DISSOLVED AND COLLOIDAL PLUTONIUM.}

The supernate from the above experiments was filtered using a $0.45 \mu \mathrm{m}$ filter. In addition, samples were filtered through a $30 \mathrm{kDa}$ filter under $\mathrm{N}_{2}$ gas using an Amicon stirred cell and a 30 $\mathrm{kDa}$ filter ( $\mathrm{Pu}$ in the range $<0.45 \mu \mathrm{m}$ and $>30 \mathrm{kDa}$ is considered to be colloidal). The solubility $(<0.45 \mu \mathrm{m})$ of ${ }^{242} \mathrm{Pu}$ over time in 1997 soil is shown in Figure 4A and in the 2004 soil is shown in Figure 4B. The solubility behavior for ${ }^{242} \mathrm{Pu}$ was similar in both experiments for the organic amended samples. The initial rapid precipitation or sorption phase was followed by stabilization of the $\mathrm{Pu}$ in the colloidal fraction $(<0.45 \mu \mathrm{m}$ and $>30 \mathrm{kDa})$. The experiment was followed over the
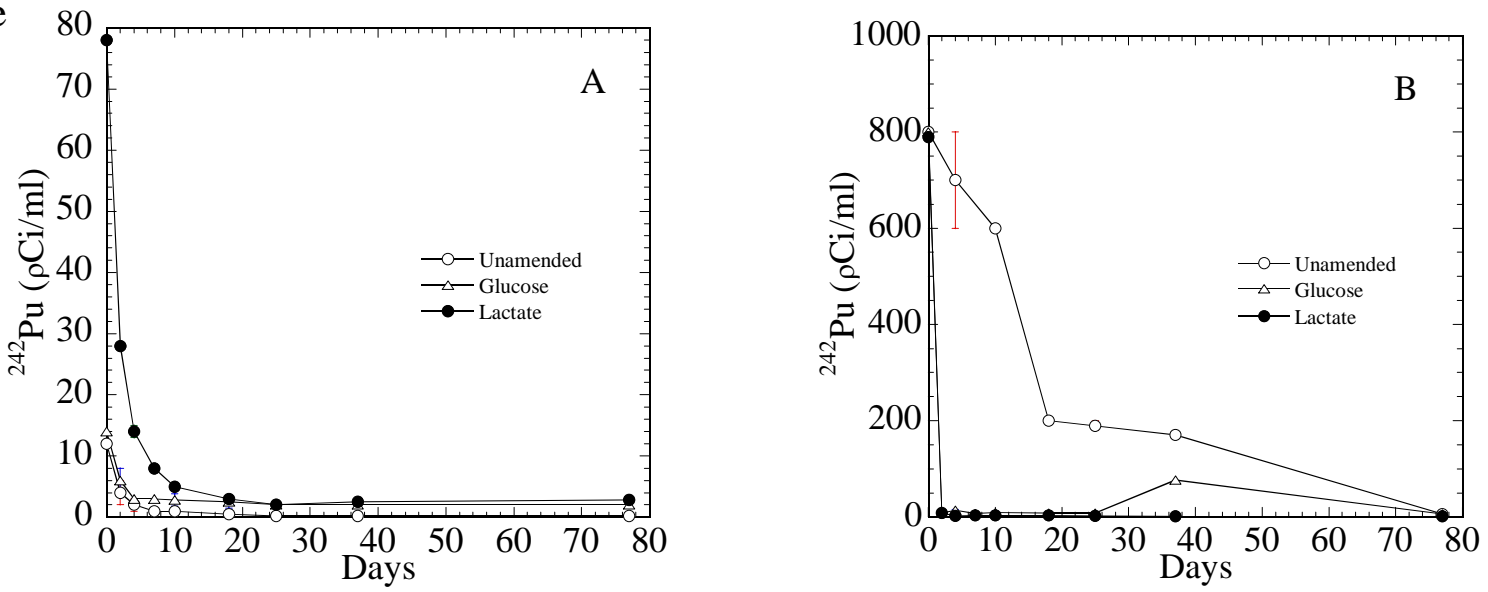

Figure $4 .{ }^{242} \mathrm{Pu}$ in colloidal fraction in the spiked incubation experiments with 1997 soil (A) and 2004 soil (B). 
long term at up 9 months without significant change in $\mathrm{Pu}$ concentration. However the ${ }^{242} \mathrm{Pu}$ behaved differently in the unamended samples with the Pu rapidly precipitating from solution in the 1997 soil experiment and remaining in solution in the 2004 experiment. The reason for this difference is not clear. Table 1 shows that highly reducing conditions were established in the amended samples by 25 days.

Table 1. Change in Eh of samples spiked with ${ }^{242} \mathrm{Pu}$.

\begin{tabular}{|c|c|c|c|}
\hline Treatment & \multicolumn{3}{|c|}{ Incubation Time (Days) } \\
\hline & 0 & 25 & 75 \\
\hline 1997 Soil & \multicolumn{3}{|c|}{ - } \\
\hline Water $+{ }^{242} \mathrm{Pu}$ & $138 \pm 15$ & $121 \pm 23$ & $75.5 \pm 9.1$ \\
\hline Glucose $+{ }^{242} \mathrm{Pu}$ & $122 \pm 20$ & $-181 \pm 14$ & $-267 \pm 20$ \\
\hline Lactate $+{ }^{242} \mathrm{Pu}$ & $131 \pm 12$ & $-123 \pm 28$ & $-366 \pm 26$ \\
\hline \multicolumn{4}{|l|}{2004 Soil } \\
\hline Water $+{ }^{242} \mathrm{Pu}$ & $146 \pm 23$ & $66 \pm 18$ & $45 \pm 14$ \\
\hline Glucose $+{ }^{242} \mathrm{Pu}$ & $136 \pm 18$ & $-137 \pm 26$ & $-240 \pm 37$ \\
\hline Lactate $+{ }^{242} \mathrm{Pu}$ & $111 \pm 7$ & $-96 \pm 17$ & $-321 \pm 16$ \\
\hline
\end{tabular}

Figure $5 \mathrm{~A}$ shows $1.86 \%$ of the ${ }^{239,240} \mathrm{Pu}$ was detected at 45 days incubation in the unfiltered fraction of the 1997 soil (filtration was not performed prior to analysis of ${ }^{239,240} \mathrm{Pu}$ ). The sample
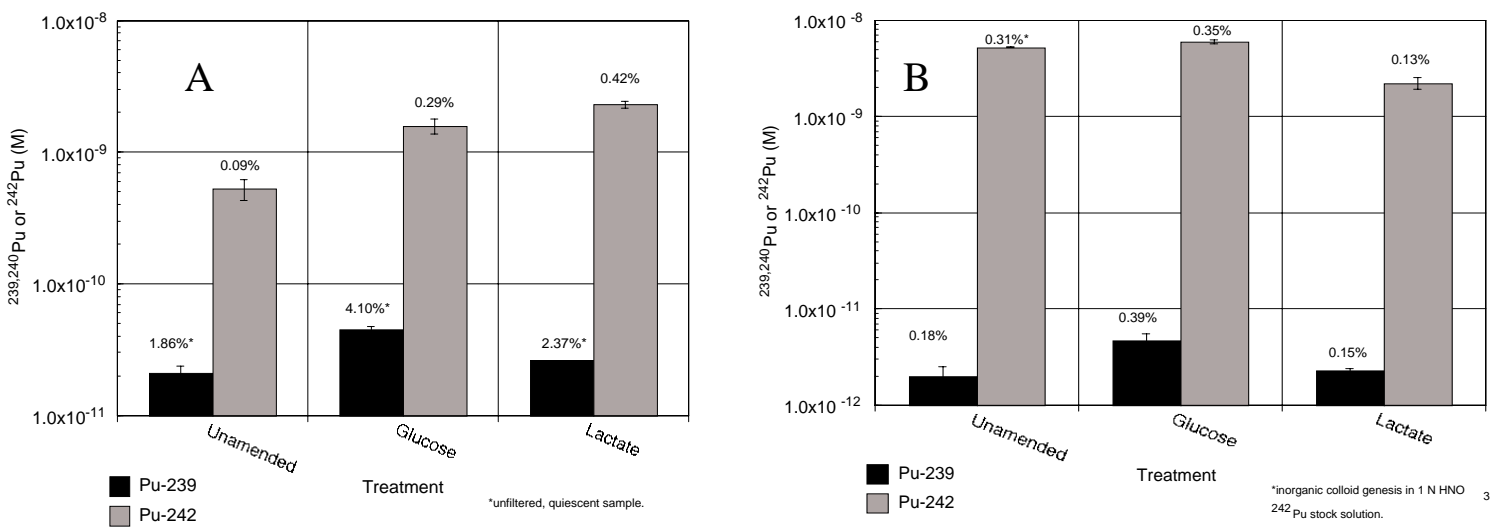

Figure 5. Comparison of the unfiltered ${ }^{239} \mathrm{Pu}$ sample at 45 days incubation to the spiked ${ }^{242} \mathrm{Pu}$ at 54 days incubation in the 1997 soil (A); and, comparison of the filtered $(<0.45 \mu \mathrm{m}){ }^{239} \mathrm{Pu}$ sample at 77 days incubation to the spiked ${ }^{242} \mathrm{Pu}$ at 77 days incubation in the 2004 soil (B).

was not shaken prior to analysis, but was decanted. It is possible that soil microparticles containing ${ }^{239,240} \mathrm{Pu}$ comprise the ${ }^{239,240} \mathrm{Pu}$ that was detected. The glucose amendment increased 
the ${ }^{239,240} \mathrm{Pu}$ content to $4.10 \%$. In the lactate amended sample, $2.37 \%$ of the total ${ }^{239,240} \mathrm{Pu}$ was detected. This result is consistent with that found in the 2004 soil incubation, where the lactate amendment had virtually no effect on ${ }^{239,240} \mathrm{Pu}$ remobilization relative to the unamended control ( 0.89 vs. $0.69 \pm 0.22 \%$ in the unfiltered aliquots, respectively) (Figure 5B). In the 2004 soil incubation study, glucose had the most significant effect on ${ }^{239,240} \mathrm{Pu}$ remobilization, with the highest amount remobilized in the unfiltered fraction and $0.39 \pm 0.02 \%$ in the $<0.45 \mu \mathrm{m}$ fraction. Note that this correlates to $69.4 \pm 11.9 \mathrm{pCi}{ }^{239,240} \mathrm{Pu} / \mathrm{L}$ and is 4.6 times higher than the EPA drinking water limit of $15 \mathrm{pCi} / \mathrm{L}$.

\section{PLANNED ACTIVITIES}

We will (i) determine the fate of Pu colloids after aerobic and anaerobic bacterial activity, (ii) characterize Pu-organic/inorganic colloids (intrinsic and pseudo colloids) generated from contaminated soil and sediment by synchrotron light source, (iii) determine the biotransformation of $\mathrm{Pu}$ associated with organic and inorganic colloids, and (iv) determine the remobilization of $\mathrm{Pu}$ associated with $\mathrm{Pu}$ hydroxide, and Pu-iron oxide due to aerobic and anaerobic bacterial action and identify the chemical speciation of released $\mathrm{Pu}$.

\section{INFORMATION ACCESS}

1. Francis, A.J.: C.J. Dodge: J.B. Gillow. 2006. Biotransformation of plutonium complexed with citric acid. Radiochim. Acta 94:731-737.

2. Dodge, C.J. Interactions of radionuclides with organic ligands: Implications for their mobility in nuclear waste. Lecture given to students in the Nuclear Chemistry Summer Science (NCSS) program, July 18, 2006.

3. Dodge, C.J. Elucidating the mechanisms of biotransformation of radionuclide-containing waste materials using synchrotron radiation. Presented to the REU Chemistry Program, SUNY-SB, July 27, 2006.

4. Yoshida, T., T. Ozaki, T. Ohnuki, and A. J. Francis. 2004. Interactions of trivalent and tetravalent heavy metal-siderophore complexes with Pseudomonas fluorescens, Radiochim. Acta 92: 749-753.

5. Kantar, C., Gillow, J.B., Harper-Arabie, R., Honeyman, B.D., and Francis, A.J. 2005. Determination of stability constants of U(VI)-Fe(III)-citrate complexes. Environ. Sci. Technol. 39: 2161-2168.

6. Suzuki Y., T. Nankawa, T. Yoshida, T. Ozaki, T. Ohnuki, A. J. Francis, S. Tsushima, Y. Enokida, and I. Yamamoto. 2005. Biodegradation of Eu(III)-citrate complexes by Pseudomonas fluorescens. J. Radioanal. Nucl. Chem. 266:199-204.

7. Ozaki, T., Y. Suzuki, T. Nankawa, T. Yoshida, T. Ohnuki, T. Kimura, A. J. Francis. Interactions of rare earth elements with bacteria and organic ligands. J Alloys Compds., 408-412: 1334-1338. 